\title{
ASSESSMENT AND FORECASTING OF FAVOURABLE CONDITIONS FOR SOCIAL ENTREPRENEURSHIP DEVELOPMENT
}

\author{
Anna Pereverzieva ${ }^{1}$, Volodymyr Volkov²
}

\begin{abstract}
The objective of the study is to develop favourable environment's assessment and forecasting methodology for social entrepreneurship development in market economies. Methodology. Econometric method to build regression model of country's favourable conditions for social entrepreneurs' relationship to its determinants is applied in the research. The research is based on previously developed multi-step algorithm: statistical data systematization, regression model building and relevant variables' selection, new regression model building excluding insignificant variables, type of regression model setting and scenario forecasting. The type of regression model that best describes the correlation nature has been determined. Scenario forecasting of country's favourable conditions' changes for social entrepreneurs based on "state policy support of social entrepreneurship development" implementation has been carried out. Three scenarios of social entrepreneurship development have been designed: pessimistic, inertial (basic) and optimistic. Research data comes from statistical databases of "The best countries to be a social entrepreneur" poll conducted by the Thomson Reuters Foundation in 2016 and 2019. Study results revealed that country's favourable conditions for social entrepreneurs' development are mostly affected by government policy support and investment access which form particular environment aimed at successful economic performance inside a country. Practical implications. Assessment and forecasting of favourable development of social entrepreneurship reveals its strengths and weaknesses that need to be improved through implementation of centralized "government policy for the development of social entrepreneurship." This enables countries not only to keep scores of "the best country for the development of social entrepreneurship", but also to improve their position in the future. Value/originality. Nowadays social entrepreneurship is becoming a tool to overcome current challenges and preserve human potential by the resurgence of innovative forms of business. One of the ways to achieve the objective is proposed in our study.
\end{abstract}

Key words: social entrepreneurship, government policy support, favourable conditions for social entrepreneurship development, access to investment, public understanding, social entrepreneur, scenario forecasting.

JEL Classification: L31, 011, C13

\section{Introduction}

Current development is characterized by the significant impact of global challenges on global economies, regardless of their level of development. However, developed countries take an advantage to meet path dependence with minimum losses to society, and developing countries do not have enough capacity to overcome today's challenges and threats.

There is an objective need to find consolidated solution and effective mechanisms that will restore capacity and ensure relevant standard of living. Social enterprises and their accelerated development become an effective tool in the context of significantly reduced households' incomes, high unemployment, growing and deepening poverty. This innovative form of business allows to meet population basic needs amid limited income, mitigates unemployment problem, applies and improves managerial skills of social entrepreneurs.

We emphasize that to promote development and effective functioning of social entrepreneurship, it is necessary to create relevant environment in the country, which depends on sustainable determinants.

We believe that the assessment of set national favourable conditions for social entrepreneurs' development together with factors that shape them is extremely important. After all, it distinguishes strengths and weaknesses that claim constant attention. Scenario forecasting allows to identify possible trends of country's economic development under governmental support of social entrepreneurship and its boosting.

\footnotetext{
Corresponding author:

${ }^{1}$ Zaporizhzhia National University, Ukraine.

E-mail: pereverzeva@ukr.net

${ }^{2}$ Zaporizhzhia National University, Ukraine.

E-mail:volkovvp49@gmail.com
} 
The results of the study have revealed that government policy support (significance of regression coefficient - 0.239) and access to investment (significance of regression coefficient -0.238 ) are the most important factors that impact the development of social entrepreneurship. Analysis have showed that social enterprise is not perceived by an entrepreneur as a way to make money and favourable environment does not depend on social enterprises' prevalence in a country. Thus, the last two factors have been found out to be insignificant.

The article has a clear structure, its elements are logically represented. Literature review is divided into separate parts, which consider: interpretation of the theoretical concept of "social entrepreneurship", government support for the development of a social enterprise and role of a social entrepreneur to ensure this effective innovative form of business performance. Detailed description of the research methodology and its approbation have been given. The article is summarized by the results and prospects for future research.

\section{Concept of "social entrepreneurship"}

The issue of "social entrepreneurship" theoretical definition is debatable. The problem solution stems from peculiarities of country's legal, economic and social environment. After all, in some countries there is no legislative regulation of social entrepreneurship, its legal status is not defined, there is no clear definition of economic features of its performance and development, assessment and social impact are not clearly explained as well.

Scholars (Zulkefly, Ghani, Alquliti) who focused on economic features of social enterprises and their social significance, proved the dominance of non-commercial goals over commercial ones, which is the main, i.e., ultimate, goal of a certain social problem solution. Nevertheless, scholars prove the complementarity of economic and social goals, if the latter prevail, in their study. At the same time, the issues of differentiation between the concept of profit and non-profit organizations (Horishna, 2016), definition of their key goal, the relationship between economic and social parts remain controversial.

Emphasizing the influence of non-commercial goals, scholars identify the following characteristics of social entrepreneurship such as self-sufficiency, financial stability and innovation (Konovalova, Kharynina, 2016). That is, along with the social effect, an important task is to maintain financially balanced functioning and development of social entrepreneurship through the introduction of innovative approaches.

Theoretical analysis of "social entrepreneurship" concept is presented in the studies of B. Drayton (Drayton, 2019), who has focused his attention on two key characteristics: innovation and the ability to tackle social problems. They induce its introduction in underdeveloped and developing countries being an essential tool for acceleration of socio-economic development.

Scholars consider that social entrepreneurship's key mission is the opportunity to change the world (Jill Kickul, Thomas S. Lyons, 2016), which is relevant amid growing global problems, the need to consolidate efforts around the world and rethink future development priorities.

\section{The role of government policy support for social entrepreneurship development}

Scholars who have analyzed peculiarities of social enterprises' activity (Agustina, Budiasih, Ariawan, Gorovoy, 2020, p. 258) demonstrate that one of the decisive determinants of the efficiency of the innovative form of business is government policy support, which primarily involves its legal regulation and legal status determination (Svynchuk, 2019), as well as economic support through fiscal policy. Moreover, social entrepreneurship is the basis for higher economic growth in the country. Besides, the significance of government policy support clearly stresses the need to articulate criteria for social business differentiation (William A. Schambra, 2010). It has been pointed out that government policy should promote introduction of social innovation at both regional and national level (Keohane, Georgia Levenson, 2013).

Scholars (Sahasranamam, Nandakumar, 2018) highlight characteristic features of public institutions' impact and role in functioning and development of social enterprises.

\section{The role of a social entrepreneur}

Indeed, a social entrepreneur is essential to any business entity regardless of the prevailing commercial or non-commercial goals.

Most scholars (Lunkina, Ivanenko, 2019; Sahasranamam, Nandakumar, 2018) are inclined to believe that the mission of social entrepreneurs requires special environment and direct correlation between the development of individual capital of social entrepreneurs and public institutions.

Scholars (Konovalova, Kharynina, 2016) have found out that social entrepreneurship as innovative form of business supports social entrepreneur's self-realization and self-improvement, as well as it affects the ability to improve managerial skills (Pryshchak, Lesko, 2016).

The critical literature review dedicated to the basis of "social entrepreneurship" theoretical concept, highlighting of the key development factors, the impact of individual human factors on the effectiveness of social enterprises' performance and their mission implementation confirms the need for such an 
innovative form of business in most countries regardless of the level of their development. Each economy faces global problems, which cannot be solved by traditional forms of business.

That is why we apply, in our opinion, key hypotheses about the development of social entrepreneurship in countries:

\begin{tabular}{|l|l|}
\hline H1: & $\begin{array}{l}\text { Government policy support is a key determinant in the } \\
\text { development of social entrepreneurship and favourable } \\
\text { economic environment building. }\end{array}$ \\
\hline H2: & $\begin{array}{l}\text { Social entrepreneurship development largely depends on } \\
\text { investment. }\end{array}$ \\
\hline
\end{tabular}

\section{Survey methodology}

To study the development of social entrepreneurship around the world we used the Thomson Reuters Foundation poll on favourable conditions for social entrepreneurship development (The best countries to be a social entrepreneur) as raw data. The poll was conducted for 43 countries in 2016 and 2019, i.e., with time lag of three years. General indicator of country's favourable conditions and impact factors have been applied for the quantitative assessment, namely: Government Policy Supports Social Entrepreneurs, Attracting Skilled Staff, Public Understanding, i.e., public awareness of social entrepreneurship aim and its importance, Making a Living, i.e., social entrepreneurship as a way of making money and life support, Gaining Momentum as social entrepreneurship promotion and Access to Investment.

Data allow to assess and forecast the development of social entrepreneurship in countries with different levels of economic development based on step-by-step algorithm (Figure 1).

The first step of the algorithm involves data systematization needed to assess and forecast favourable conditions. Favourable conditions for social entrepreneurship development (Y) and their impact factors $\left(X_{i}, i=\overline{1,6}\right)$ are qualitative variables estimated as percentage. For quantitative analysis, indicators as a fraction of a unit are transformed into indices.

As a result of the regression model building, it has been revealed that $\mathrm{X} 5$ determinant is insignificant (by insignificance characteristics of the regression model), so country's favourable conditions for social entrepreneurship do not depend on this form of business promotion (Gaining Momentum). The complete equation of the regression model is presented as:

$$
\begin{aligned}
& Y=0,046+0,224 X_{1}+0,123 X_{2}+0,204 X_{3}+ \\
& +0,045 X_{4}+0,183 X_{5}+0,150 X_{6}, \\
& \text { Coefficient of determination } R^{2}=0,9757
\end{aligned}
$$

A new regression model with relevant determinants is built as the next step of the algorithm.

$$
\begin{aligned}
& Y=0,129+0,237 X_{1}+0,160 X_{2}+ \\
& +0,205 X_{3}+0,055 X_{4}+0,208 X_{6},
\end{aligned}
$$

Coefficient of determination $R^{2}=0,9591$.

$\mathrm{X}_{4}$ determinant has been revealed as insignificant (Making a Living), which demonstrates social entrepreneurs' ability to earn a living.

Next step is to build a new regression model not taking into consideration determinants $\mathrm{X}_{5}$ and $\mathrm{X}_{4}$ :

$Y=0,141+0,239 X_{1}+0,173 X_{2}+0,2 X_{3}+0,238 X_{6}$, (3)

Coefficient of determination $R^{2}=0,9157$.

All determinants are significant in the obtained new formula of the model (3), that is country's favourable conditions for social entrepreneurship depend on: government policy support of social enterprises $\left(X_{1}-\right.$ Government policy supports social

\begin{tabular}{|c|c|}
\hline STEP 1 & Statistics systematization \\
\hline STEP 2 & Building general regression model and identification of insignificant variables \\
\hline STEP 3 & Building a new regression model by relevant determinants \\
\hline STEP 4 & $\begin{array}{l}\text { Identification of the regression model's type, which illustrates correlation between } \\
\text { country`s favourable conditions for social entrepreneurship development and relevant } \\
\text { components }\end{array}$ \\
\hline STEP 5 & $\begin{array}{l}\text { Development of scenario forecasting amid implementation of } \\
\text { "Government policy support for social entrepreneurs" }\end{array}$ \\
\hline
\end{tabular}
entrepreneurs), skilled staff attraction $\left(\mathrm{X}_{2}-\right.$ Attracting Skilled Staff), understanding of social enterprises' goals $\left(\mathrm{X}_{3}-\right.$ Public Understanding) and access to investment ( $\mathrm{X}_{6}-$ Access to Investment).

Figure 1. Step-by-step algorithm of the assessment and forecasting of country's favourable conditions for social entrepreneurship development

Source: built by authors themselves 
Table 1

Country's favourable conditions for social entrepreneurship development and impact factors

\begin{tabular}{|c|c|c|c|c|c|c|c|}
\hline Country by ranking & $\begin{array}{c}\text { The best } \\
\text { countries to } \\
\text { be a social } \\
\text { entrepreneur }\end{array}$ & $\begin{array}{c}\text { Government } \\
\text { policy } \\
\text { supports social } \\
\text { entrepreneurs }\end{array}$ & $\begin{array}{l}\text { Attracting } \\
\text { Skilled Staff }\end{array}$ & $\begin{array}{c}\text { Public } \\
\text { Understanding }\end{array}$ & $\begin{array}{l}\text { Making a } \\
\text { Living }\end{array}$ & $\begin{array}{c}\text { Gaining } \\
\text { Momentum }\end{array}$ & $\begin{array}{l}\text { Access to } \\
\text { Investment }\end{array}$ \\
\hline & $\mathrm{Y}$ & $\mathrm{X}_{1}$ & $\mathrm{X}_{2}$ & $\mathrm{X}_{3}$ & $\mathrm{X}_{4}$ & $\mathrm{X}_{5}$ & $\mathrm{X}_{6}$ \\
\hline Canada & 0.7187 & 0.7292 & 0.6875 & 0.5625 & 0.7708 & 0.9583 & 0.6250 \\
\hline Australia & 0.6450 & 0.6818 & 0.5000 & 0.5417 & 0.7708 & 0.8333 & 0.5455 \\
\hline France & 0.6377 & 0.7083 & 0.6458 & 0.4375 & 0.6250 & 0.7917 & 0.5000 \\
\hline Belgium & 0.6170 & 0.7000 & 0.4773 & 0.4773 & 0.6667 & 0.8409 & 0.6136 \\
\hline Singapore & 0.5972 & 0.7708 & 0.2708 & 0.5000 & 0.5208 & 0.8125 & 0.5000 \\
\hline Denmark & 0.5957 & 0.5455 & 0.8182 & 0.5417 & 0.4545 & 0.7708 & 0.3409 \\
\hline Netherlands & 0.5896 & 0.5625 & 0.5417 & 0.3958 & 0.6250 & 0.7917 & 0.4773 \\
\hline Finland & 0.5860 & 0.5833 & 0.7727 & 0.4375 & 0.7708 & 0.6875 & 0.3636 \\
\hline Indonesia & 0.5758 & 0.5208 & 0.4583 & 0.4167 & 0.5625 & 0.9167 & 0.4091 \\
\hline Chile & 0.5712 & 0.5417 & 0.5833 & 0.5833 & 0.4583 & 0.7917 & 0.4792 \\
\hline Israel & 0.5702 & 0.6042 & 0.6458 & 0.4375 & 0.5000 & 0.8333 & 0.3409 \\
\hline United Arab Emirates & 0.5664 & 0.4375 & 0.6458 & 0.4375 & 0.5625 & 0.8125 & 0.3750 \\
\hline United Kingdom & 0.5556 & 0.5625 & 0.6250 & 0.3542 & 0.6042 & 0.7727 & 0.3750 \\
\hline Pakistan & 0.5543 & 0.3958 & 0.7083 & 0.5000 & 0.7708 & 0.7083 & 0.4091 \\
\hline South Korea & 0.5533 & 0.7500 & 0.3864 & 0.4167 & 0.5000 & 0.6667 & 0.3750 \\
\hline Sweden & 0.5459 & 0.6042 & 0.7045 & 0.3542 & 0.5625 & 0.7917 & 0.3182 \\
\hline Switzerland & 0.5458 & 0.4583 & 0.6250 & 0.5208 & 0.4773 & 0.6667 & 0.2708 \\
\hline Italy & 0.5401 & 0.4375 & 0.7083 & 0.6250 & 0.6042 & 0.6458 & 0.4091 \\
\hline Hong Kong & 0.5398 & 0.5833 & 0.4375 & 0.4583 & 0.3125 & 0.7292 & 0.3636 \\
\hline India & 0.5386 & 0.5000 & 0.5417 & 0.3750 & 0.5625 & 0.7917 & 0.4091 \\
\hline Germany & 0.5294 & 0.3864 & 0.6667 & 0.4375 & 0.5625 & 0.8333 & 0.2955 \\
\hline Philippines & 0.5284 & 0.4792 & 0.4773 & 0.3750 & 0.6607 & 0.6875 & 0.3958 \\
\hline Russia & 0.5207 & 0.6750 & 0.3958 & 0.3958 & 0.6458 & 0.7292 & 0.3500 \\
\hline Egypt & 0.5183 & 0.4545 & 0.5417 & 0.4167 & 0.5208 & 0.8409 & 0.3542 \\
\hline Thailand & 0.5183 & 0.6458 & 0.4793 & 0.4167 & 0.5625 & 0.7292 & 0.3864 \\
\hline Argentina & 0.5107 & 0.5000 & 0.6818 & 0.3750 & 0.4792 & 0.7292 & 0.3636 \\
\hline Austria & 0.5052 & 0.4583 & 0.5833 & 0.3125 & 0.4375 & 0.7500 & 0.2955 \\
\hline Greece & 0.5039 & 0.5000 & 0.375 & 0.3125 & 0.425 & 0.6818 & 0.3542 \\
\hline Nigeria & 0.5017 & 0.4167 & 0.5625 & 0.4167 & 0.4792 & 0.7500 & 0.3542 \\
\hline Malaysia & 0.4940 & 0.5833 & 0.3636 & 0.3750 & 0.5000 & 0.7083 & 0.2727 \\
\hline Spain & 0.4871 & 0.3750 & 0.6458 & 0.2920 & 0.4545 & 0.7500 & 0.3864 \\
\hline United States & 0.4790 & 0.3750 & 0.5625 & 0.3958 & 0.6042 & 0.7045 & 0.2045 \\
\hline Norway & 0.4774 & 0.5208 & 0.6042 & 0.2917 & 0.5417 & 0.7083 & 0.2727 \\
\hline South Africa & 0.4770 & 0.2917 & 0.5417 & 0.3750 & 0.6042 & 0.8542 & 0.2708 \\
\hline Poland & 0.4497 & 0.6667 & 0.3333 & 0.1875 & 0.5258 & 0.5833 & 0.2917 \\
\hline Ireland & 0.4377 & 0.4375 & 0.5208 & 0.2083 & 0.5417 & 0.7708 & 0.2727 \\
\hline China & 0.4375 & 0.4792 & 0.375 & 0.2708 & 0.4375 & 0.5625 & 0.4167 \\
\hline Brazil & 0.4200 & 0.2273 & 0.5208 & 0.3333 & 0.4583 & 0.6875 & 0.275 \\
\hline Colombia & 0.4171 & 0.2500 & 0.4167 & 0.3542 & 0.6042 & 0.7292 & 0.3182 \\
\hline Venezuela & 0.4048 & 0.1458 & 0.4583 & 0.5625 & 0.3542 & 0.5625 & 0.1875 \\
\hline Japan & 0.4039 & 0.3409 & 0.4318 & 0.3409 & 0.4545 & 0.6042 & 0.3182 \\
\hline Turkey & 0.3813 & 0.1875 & 0.6250 & 0.2500 & 0.3958 & 0.7500 & 0.1591 \\
\hline Mexico & 0.3643 & 0.1667 & 0.5000 & 0.2083 & 0.5417 & 0.5833 & 0.2708 \\
\hline
\end{tabular}

Source: data integration by the authors [The best countries to be a social entrepreneur $2019 \mathrm{http}: / /$ poll2019.trust.org/] 
The second step of the algorithm defines the type of function, which accurately describes correlation (Table 2).

Table 2

Functions of correlation between country's favourable conditions for social entrepreneurship development and impact factors

\begin{tabular}{|c|c|}
\hline Type of model & Coefficient of determination $\mathrm{R}^{2}$ \\
\hline Linear & 0.9157 \\
\hline Power & 0.9030 \\
\hline Indicative & 0.8908 \\
\hline Hyperbolic & 0.8006 \\
\hline Quadratic & 0.8006 \\
\hline Logarithmical & 0.8801 \\
\hline Root & 0.8935 \\
\hline
\end{tabular}

Source: calculated by the authors themselves

Thus, we choose a linear function as a basis, because it has the highest coefficient of determination $\mathrm{R}^{2}=0.9157$ and it is analytically represented by formula 1. Coefficients of significance before model variables indicate that government support has the biggest influence on the country's favourable conditions for social enterprise development ( $\mathrm{X}_{1}$ with 0.239 coefficient of significance). Access to investment ( $\mathrm{X}_{6}$ with 0.238 coefficient of significance) occupies the second place. This confirms hypotheses $\mathrm{H} 1$ and $\mathrm{H} 2$. The third most important factor is public understanding of social enterprises' goals and their perception ( $\mathrm{X}_{3}$ with 0.200 coefficient of significance). Attraction of skilled staff has the lowest impact on favourable conditions ( $\mathrm{X}_{2}$ with 0.173 coefficient of significance).

Table 3

Factors' growth rates, which impact country's favourable conditions for social entrepreneurship development (case of Canada)

\begin{tabular}{|c|c|c|c|c|c|}
\hline \multirow{3}{*}{ Country } & \multirow{3}{*}{ Year } & $\begin{array}{c}\text { Government policy } \\
\text { supports social } \\
\text { entrepreneurs }\end{array}$ & Attracting Skilled Staff & Public Understanding & Access to Investment \\
\cline { 2 - 6 } & 2019 & $\mathrm{X}_{1}$ & $\mathrm{X}_{2}$ & $\mathrm{X}_{3}$ & $\mathrm{X}_{6}$ \\
\hline \multirow{3}{*}{ Canada } & 2016 & 0.7292 & 0.6875 & 0.5625 & 0.625 \\
\cline { 2 - 6 } & average increment rate & $\mathbf{1 . 0 3}$ & 0.6875 & 0.479 & 0.583 \\
\hline
\end{tabular}

Source: calculated by the authors applying data [The best countries to be a social entrepreneur 2016: http://poll2016.trust.org/; The best countries to be a social entrepreneur 2019: http://poll2019.trust.org/]

Table 4

Scenario forecasting of social entrepreneurship development, 2022 (case of Canada)

\begin{tabular}{|c|c|c|c|c|}
\hline \multirow{3}{*}{ Scenario forecasting } & $\begin{array}{c}\text { Government policy supports } \\
\text { social entrepreneurs }\end{array}$ & Attracting Skilled Staff & Public Understanding & Access to Investment \\
\hline & \multicolumn{4}{|c|}{ Increment rate } \\
\hline & $\mathrm{X}_{1}$ & $\mathrm{X}_{2}$ & $\mathrm{X}_{3}$ & $\mathrm{X}_{6}$ \\
\hline Pessimistic & 1.06 & 1.01 & 1.18 & 1.08 \\
\hline Inertial & 1.07 & 1.02 & 1.19 & 1.09 \\
\hline Optimistic & 1.08 & 1.03 & 1.2 & 1.2 \\
\hline
\end{tabular}

Source: developed by authors themselves
The method of forecasting of the country's favourable conditions should be proposed on the basis of the obtained results in case it implements government policy support of the innovative form of business. We provide forecasting by the example of Canada, the best country in the ranking in 2019. Let us calculate changes in country's favourable conditions for social entrepreneurship development and coefficients of significance according to the model (formula 3 ) for the country in 2016 and 2019 (Table 3).

Based on Table 3 data, let us calculate increment rate for a 3-year period (2016-2019s) by the formula:

$$
T_{X_{i}}=\frac{X_{i}^{2019}}{X_{n}^{2016}},
$$

where $T_{X_{i}}-$ determinant's increment rate

$X_{i}^{2019}$ - value of the determinant $X_{i}, i=1,2,3,6$ in 2019, $X_{i}^{2016}$ - value of the determinant $X_{i}, i=1,2,3,6$ in 2016.

The calculated rating of increment rate's value allows us to forecast country's favourable conditions for social entrepreneurship development by 2022, if other impact factors remain equal.

Taking into consideration the necessity of all countries to tackle global challenges, we believe that to achieve a high level of development, it is necessary not only to fix own position, but to improve it by implementing "government policy support for social entrepreneur's development", preserve human resources and meet their basic needs understanding significant income reduction.

Scenario forecasting of social development based on "Government policy support for social entrepreneurs" is presented in Table 4 . $X_{i}, i=1,2,3,6$, 
Table 5

Calculation of country's favourable conditions for social entrepreneurship development changes, 2022 (case of Canada)

\begin{tabular}{|c|c|c|c|c|c|}
\hline \multirow[t]{2}{*}{ Scenario forecasting } & $\begin{array}{c}\text { Government policy } \\
\text { supports social } \\
\text { entrepreneurs }\end{array}$ & $\begin{array}{l}\text { Attracting } \\
\text { Skilled Staff }\end{array}$ & $\begin{array}{c}\text { Public } \\
\text { Understanding }\end{array}$ & $\begin{array}{l}\text { Access to } \\
\text { Investment }\end{array}$ & $\begin{array}{c}\text { The best countries } \\
\text { to be a social } \\
\text { entrepreneur }\end{array}$ \\
\hline & $\mathrm{X}_{1}$ & $\mathrm{X}_{2}$ & $\mathrm{X}_{3}$ & $\mathrm{X}_{6}$ & $\mathrm{Y}$ \\
\hline $\begin{array}{l}\text { Without implementation of "government } \\
\text { policy support of social entrepreneurs" }\end{array}$ & 0.740 & 0.729 & 0.804 & 0.602 & 0.750 \\
\hline Pessimistic & 0.762 & 0.736 & 0.811 & 0.608 & 0.759 \\
\hline Inertial & 0.769 & 0.744 & 0.818 & 0.613 & 0.765 \\
\hline Optimistic & 0.776 & 0.751 & 0.825 & 0.675 & 0.784 \\
\hline
\end{tabular}

Source: calculated by authors themselves

Three scenarios have been used for forecasting in case of "government policy support of social entrepreneurship development" implementation: pessimistic, inertial, and optimistic. Increment rates for each of the scenarios have been determined on the basis of the calculated increment rates in Table 3. In the pessimistic scenario, government policy support $\left(\mathrm{X}_{1}\right)$ will increase by $6 \%$, the possibility of attracting qualified staff $\left(\mathrm{X}_{2}\right)$ by $1 \%$, public understanding of social enterprises' goals $\left(\mathrm{X}_{3}\right)$ by $18 \%$, access to investment $\left(\mathrm{X}_{6}\right)$ by $8 \%$. In the inertial scenario, growth rates of the studied factors are $7 \%, 2 \%, 19 \%$, $9 \%$, respectively. Impact factors make much progress in the development of social entrepreneurship in the optimistic scenario - 8\%, 3\%, 20\%, 10\%, respectively.

According to the regression model and scenario forecasting built by us, one can calculate country's favourable conditions for social entrepreneurship development changes (Table 5).

According to polling results for 2019, Canada is the best country having 0.719 level of favourable conditions of social entrepreneurship development. The obtained calculations demonstrate the level's growth by 0.750 if "social entrepreneurship development policy" would not have been introduced in 2022. Taking into consideration risks that affect all countries around the world, lack of progressive changes does not allow countries to maintain and improve their position. Therefore, introduction of "government policy support of social entrepreneurs' development" is an objective basis of further economic development preservation. It should be noted that introduction of "government policy support of social entrepreneurs' development" both in optimistic and in pessimistic scenarios provides marked increase in social entrepreneurship development $\mathrm{Y}=0.759$ (Table 5).

Graphical interpretation of scenario forecasting of social entrepreneurship development in Canada is presented by Figure 2 .

Figure 2 clearly illustrates that optimistic scenario reveals the largest growth in the country's favourable conditions for social entrepreneurship development,

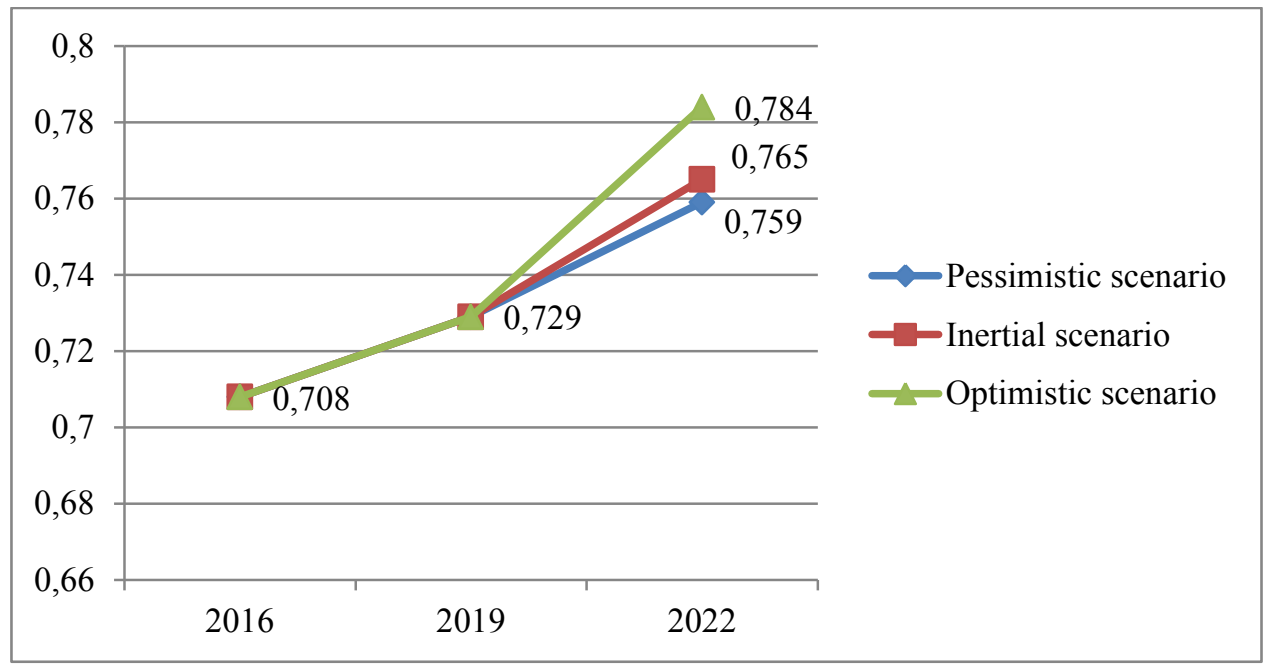

Note: axis of abscissas - years; axis of ordinates - index (level) of country's favourable conditions for social entrepreneurship development

Figure 2. Scenario forecasting graph of social entrepreneurship development (case of Canada)

Source: built by authors themselves 
which confirms the need to start and enhance "government policy support of social entrepreneurs' development" in the context of higher global challenges and economic risks.

\section{Findings}

To determine the nature of correlation between country's favourable environment for social entrepreneurship development and impact factors, regression analysis have been used by us. Thus, we have detailed significant and insignificant components and proposed the model that relevantly describes the nature of dependence: linear regression model.

According to the analysis results, the following groups of factors have been identified:

significant (relevant): $\mathrm{X}_{1}-$ government support (Government policy supports social entrepreneurs), $\mathrm{X}_{2}$ - attraction of qualified staff (Attracting Skilled Staff), $\mathrm{X}_{3}$ - public understanding, i.e., public awareness of social entrepreneurship aims and their importance (Public Understanding) and $\mathrm{X}_{6}-$ availability of investment (Access to Investment);

insignificant (irrelevant): $\mathrm{X}_{4}$ - social entrepreneurship as an ability to earn a living (Making a Living), $\mathrm{X}_{5}-$ social entrepreneurship extensive promotion (Gaining Momentum).

Analysis of the coefficients of significance have found out that the most important determinants for the assessment and forecasting of favourable conditions for social entrepreneurship development are government policy support (coefficient of significance 0.239 ), access to investment (coefficients of significance 0.238), public understanding (coefficients of significance 0.200 ), attraction of skilled staff (coefficients of significance 0.173).

Our assessment and scenario forecasting of social entrepreneurship development allowed us to conclude that there is urgent need to introduce "government policy support of social entrepreneurs' development" to keep the status of the "welfare nation" and "economy with a human face", which indicates the trend towards a human-centered economy as the most important priority for the future development of the state and society.

For convenience, we summarize the results of the hypotheses in the table below:
Table 6

Summary of findings

\begin{tabular}{|l|l|}
\hline Hypotheses: & \\
\hline $\begin{array}{l}\text { H1: Government support is the key determinant of } \\
\text { social entrepreneurship development and favourable } \\
\text { environment building }\end{array}$ & Adopted \\
\hline $\begin{array}{l}\text { H2: Social entrepreneurship development largely } \\
\text { depends on investment }\end{array}$ & Adopted \\
\hline
\end{tabular}

Source: own study

\section{Conclusions}

Methodology of assessment and forecasting country's favourable conditions for social entrepreneurship development as an effective form of business to meet population basic needs in market economies amid scarce resources has been proposed in the article. Regression analysis has been applied as an analytical method. Relevant mathematical model to describe characteristic correlation between country's favourable conditions for social entrepreneurship and correct factors has been built. Government support and access to investment have been considered as the most influential determinants. The model is based on the statistical survey in 43 economies.

We have proposed to implement "government policy support of social entrepreneurs' development", which allows not only to keep the status of the top country for social entrepreneurs, but also improve results for the future.

The scenario forecasting has been made applying the example of Canada as the top nation by favourable conditions for social entrepreneurship development in 2019. Graphical interpretation of the scenario forecasting with the comparison of each scenario has been presented. The method of forecasting is universal and can be used for countries with any level of economic development.

Our work is not without limitations. We propose only one method to assess and forecast country's favourable conditions for social entrepreneurship development. This method does not fully take into account all unpredictable challenges and risks that are impossible to expect in advance. Improvement of the proposed methodology taking into consideration maximum number of risks, which certainly affect accuracy of future scenarios' assessment and forecasting is the subject of further research.

\section{References:}

Zulkefly, N. A., Ghani, N. A., \& Alquliti, W. (2019). Identification of variables in predicting trends in social entrepreneurship. International Conference Computer Science and Engineering. Journal of Physics: Conference Series. 26-27 April. Padang, Indonesia, vol. 1339, no. 1. doi: 10.1088/1742-6596/1339/1/012025

Agustina, T., Budiasih, Y., Ariawan, K. E., \& Gorovoy, S. A. (2020). Role of social entrepreneurship in business management. Journal of Critical Reviews, vol. 7, no. 1, pp. 257-262.

Sahasranamam, S., \& Nandakumar, M. K. (2020). Individual capital and social entrepreneurship: Role of formal institutions. Journal of Business Research, vol. 107, pp. 104-117. doi: https://doi.org/10.1016/j.jbusres.2018.09.005 
Konovalova, M. V., \& Kharynina, O. M. (2016). Sotsialne pidpryiemstvo yak innovatsiinyi sposib vyrishennia sotsialnykh problem [Social enterprise as an innovative way of solving social problems]. Visnyk KamianetsPodilskoho natsionalnoho universytetu imeni Ivana Ohiienka. Ekonomichni nauky, vol. 11, pp. 461-466. Retrieved from: http://nbuv.gov.ua/UJRN/vkpnuen_2016_11_64 (accessed 15 March 2020)

Horishna, N. M. (2016). Fenomen sotsialnoho pidpryiemnytstva: sutnist i kryterii [The phenomenon of social entrepreneurship: essence and criteria]. Naukovyi Visnyk Uzhhorodskoho universytetu. Seriia: «Pedahohika. Sotsialna robota», vol. 2, no. 39, pp. 58-61. (in Ukrainian)

Drayton, B. (2019). Social entrepreneurs don't want to help. They want to change the world. THE FOCUS, vol. XII, no. 2, pp. 53-57. Retrieved from: https://www.egonzehnder.com/cdn/serve/article-pdf/1513691150c700cbda2b13bb4b6440f602b8d23ef1.pdf (accessed 15 March 2020).

Kickul, J., \& Thomas, S. Lyons (2016). Understanding Social Entrepreneurship: The Relentless Pursuit of Mission in an Ever Changing World. United Kingdom: Routledge.

Svinchuk, A. (2019). Rol derzhavi u rozvitku social'nogo pidpriemnictva: evropejs'kij ta amerikanskij dosvid [The role of power in developing social welfare: Europe and America]. Retrieved from: http://www.socialbusiness.in.ua/ index.php/novyny/v-sviti (accessed 15 March 2020).

William A. Schambra (2010). The Real Social Entrepreneurs. Manhattan Institute for Policy Research, New York City, 9 December 2010. Retrieved from: https://www8.gsb.columbia.edu/ (accessed 15 March 2020).

Keohane, Georgia Levenson (2013). Social Entrepreneurship for the 21st Century: Innovation Across the Nonprofit, Private, and Public Sectors, New York: mc Graw Hill.

Pryshchak, M. D., \& Lesko, O. Y. (2016). Psykholohiia upravlinnia v orhanizatsii [Management psychology in organization]. Vinnytsia: VNTU. (in Ukrainian)

Lunkina, T. I., \& Ivanenko, H. Yu. (2019). Osoblyvosti rozvytku sotsialnoho pidpryiemnytstva: zakordonnyi dosvid [Features of the development of social entrepreneurship: foreign experience]. Modern Economics, vol. 5, pp. 142-147. Retrieved from: https://modecon.mnau.edu.ua (accessed 15 March 2020).

The best countries to be a social entrepreneur 2016. Retrieved from: http://poll2016.trust.org/ (accessed 15 March 2020).

The best countries to be a social entrepreneur 2019. Retrieved from: http://poll2019.trust.org/ (accessed 15 March 2020). 